\title{
Fibrosarcoma in the saddle area in a dressage horse
}

\author{
Anke Kösterl, Kernt Köhler², Eberhard Mettenleiter', Laura Brachthäuser², Gerhard Loesenbeck und Bianca Carstanjen ${ }^{7}$ \\ Pferdeklinik Sudenhof, Hagen a.T.W. ${ }^{1}$, Instituł für Veterinär-Pathologie, Justus-Liebig-Universität Gießen ${ }^{2}$ und Laboklin GmbH\&Co KG, Bad Kissingen ${ }^{3}$
}

\begin{abstract}
Summary
An eight-year-old Hanoverian gelding was presented with a progressively growing mass in the left cranial region of the saddle area and a history of riding problems. A firm, poorly circumscribed, non-painful tissue was palpable. Diagnostic imaging revealed a calcified mass in the depth of the swelling. This calcified mass was excised out of the musculus longissimus thoracis under general anesthesia. Post surgery the horse developed a non-healing and intermittendly profusely bleeding wound. During the treatment of this non-healing wound tissue samples were sent to a laboratory for histopathological and immunohistochemical analysis. The analysis confirmed a fibrosarcoma. The horse was euthanized because of a very poor prognosis.
\end{abstract}

Keywords: Horse / fibrosarcoma / neoplasia / ossification / oncology

\begin{abstract}
Fibrosarcom in der Sattellage bei einem Dressurpferd
Vorgestellt wurde ein achtjähriger Hannoveraner Wallach, der vorberichtlich eine progressiv wachsende Schwellung in der Sattellage und fortschreitende Rittigkeitsprobleme zeigte, die sich insbesondere in einer Verschlechterung der Anlehnung äußerten. Palpatorisch stellte sich die Umfangsvermehrung als eine harte, schlecht abgrenzbare, nicht druckdolente Gewebsveränderung dar. Zur weiteren Diagnostik wurden bildgebende Verfahren eingesetzt, in denen eine kalzifizierte Masse in der Tiefe der Schwellung festzustellen war. Diese kalzifizierte Masse wurde in Vollnarkose chirurgisch entfernt. Postoperativ stellte sich die Operationswunde als nicht heilend und zu Blutungen neigend dar. Im Zuge der Behandlung der Wundheilungsstörung wurden Gewebsproben entnommen, die pathomorphologischen und immunhistologischen Untersuchungen zugeführt wurden. Die Ergebnisse dieser Untersuchungen ließen die Diagnose Fibrosarkom treffen. Aufgrund dieser infausten Prognose ist das Pferd euthanasiert worden.
\end{abstract}

Schlüsselwörter: Pferd / Fibrosarkom / Tumor / Verknöcherung / Onkologie

\section{Introduction}

Fibrosarcoma is a malignant tumor (Hendrick et al. 1998), which occurs rarely in horses (Story et al. 2005, Valentine 2006) and has a high tendency to recur (Story et al. 2005). This case report describes clinical signs and diagnosis of a fibrosarcoma, associated with a non-healing surgical wound, at the location of the saddle in an adult horse.

\section{Case history}

An eight-year-old Hanoverian gelding, chestnut, high level dressage horse, was presented to the clinic for a slowly growing swelling in the left saddle region. According to the owner the horse showed resistance against the rider since more than eight months. During the last weeks the horse had a history of gait irregularities, intermittent stumbling and even falling.

\section{Clinical findings}

On admission at the clinic the gelding appeared in good body condition. The general clinical examination was normal. The horse was vaccinated (tetanus, influenza, herpes) and dewormed. The left side of the saddle region (back and left lateral region) showed a $15 \mathrm{~cm} \times 20 \mathrm{~cm}$ swelling without any skin lesion. The swelling was firm, non-mobile and non-painful at palpation and the swelling's temperature corresponded to the body surface temperature. At palpation, a delimitation of the mass and subcutaneous and muscular tissue was not possible. The horse showed a reduced mobility of the back at a walk and trot on a straight line on firm and soft surface. The examination of the back revealed a reduced mobility of the spine. Radiographic examination of the region of the swelling revealed a radiodense, i.e. calcified, region (about $10 \mathrm{~cm} x$ $2 \mathrm{~cm}$ ) (Figure 1). Ultrasonographic examination of the cutaneous swelling revealed a $12 \mathrm{~cm}$ long region with a hyperechoic border in a depth of about $8 \mathrm{~cm}$ to $10 \mathrm{~cm}$ in the musculus longissimus thoracis. The echogenicity of the soft tissue situated dorsally to the ossification appeared comparable with the soft tissue of the corresponding contralateral side, i.e. right side. Based on the swelling's location, extend and the calcification grade, a surgical excision of the calcified mass was requested by the owner.

\section{Clinical course}

The gelding's pre-anaesthetic examination was normal. Penicillin (20000IU/kg, IM; Procain Penicillin; Albrecht GmbH; Aulendorf, Germany) and phenylbutazone $(2.2 \mathrm{mg} / \mathrm{kg}, I \mathrm{I}$; Phenylbutazone ${ }^{\circledR}$; CP Pharma, Burgdorf, Germany) were administered $30 \mathrm{~min}$ prior to general anesthesia. The gelding received romifidine $\left(0.08 \mathrm{mg} / \mathrm{kg}\right.$, IV, Sedivet ${ }^{\circledR}$, Boehringer, Boehringer Ingelheim, Germany) for sedation 15 min prior to induction. Induction was performed with ketamine $\left(2.2 \mathrm{mg} / \mathrm{kg}, \mathrm{IV}\right.$; Ursotamin ${ }^{\circledR}$, Serumwerke Bernburg AG; Bernburg, Germany) and diazepam $(0.2 \mathrm{mg} / \mathrm{kg}$, IV; Diazepam $10 \mathrm{mg}{ }^{\circledR}$; Rotexmedica GmbH; Trittau, Germany). He was intubated with an oro-tracheal tube and was placed in right lateral recumbency. Anesthesia was maintained with isoflurane 
(IsoFlo ${ }^{\circledR}$, Albrecht $\mathrm{GmbH}$, Aulendorf, Germany) vaporized in oxygen. The region of the swelling was prepared aseptically. A straight skin incision was performed along the length of the calcification, which was bluntly excised. An extended hematoma -below the calcified plate- was manually evacuated. The soft tissue around the calcified plate showed no palpable pathologic changes at the moment of the surgery. A Penrosedrain was installed (WDT, Garbsen, Germany) and the skin was sutured with horizontal mattress sutures (1USP, DafiIonTM; Braun Vetcare, Germany). Recovery from anaesthesia was uneventful.

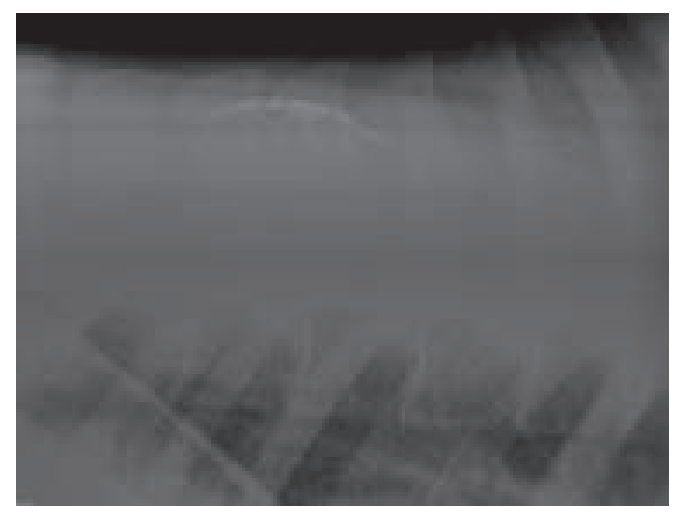

Fig. 1 Radiography of the thoracial region at the level of the soft tissue swelling. Calcified region within the soft tissue. View: Lateral projection.

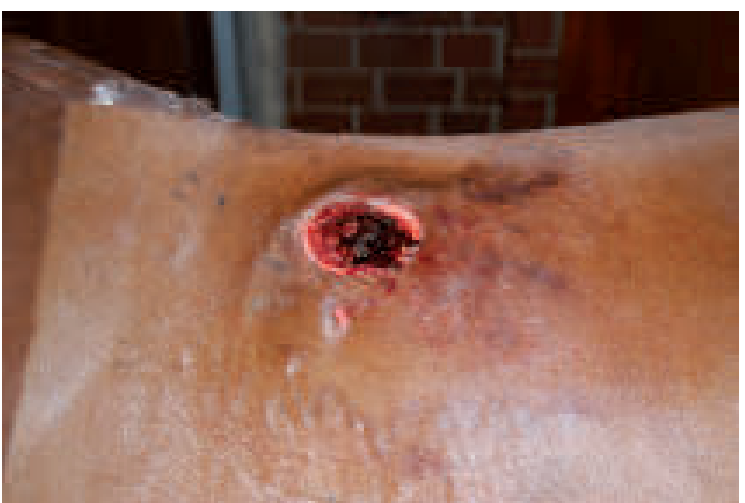

Fig. 2 Wound at day 40 post surgery. Wound healing was complicated by suture dehiscence and an intermittently profusely bleeding tissue.

The postoperative medication consisted in penicillin $(22000$ $\mathrm{IU} / \mathrm{kg}, I M, S I D)$ for five days, phenylbutazone $(2.2 \mathrm{mg} / \mathrm{kg}$, POS, BID; Equipalazone ${ }^{\circledR}$; Medistar $\mathrm{GmbH}$, Germany) for five days and tape changes as needed. The drain was removed 3 days post surgery. Wound dehiscence occurred 14 days post operationem and second intention wound healing was complicated by episodes of profuse bleeding and focal hypergranulation tissue formation (Figure 2). A biopsy of the intermittently bleeding tissue was performed at day 35 post surgery. At day 112 post surgery, the horse was euthanized on the owner's request, because of the insufficient wound-healing process.

\section{Pathology, histopathology and immunohistochemistry}

At necropsy there was a $15-20 \mathrm{~cm}$ in diameter irregular firm mass in the subcutaneous tissue of the left saddle region, about $15 \mathrm{~cm}$ left paramedian. The skin was ulcerated with adherent coagulated blood and exsudate. On cut surface the tissue was yellowish white and firm. The mass infiltrated the surrounding soft tissue and musculature. Other organs and lymph nodes were without relevant lesions. There were no obvious signs of metastasis. Histopathologically near the ulcerated skin there was a subacute inflammation with neutrophils, macrophages and numerous fibroangioblasts forming a granulation tissue (Figure 3). In the deeper areas of tissue there was an infiltrative growing mass composed of monomorphous spindle cells arranged in whorls and bundles with oval to elongated nuclei, prominent nucleoli and abundant eosinophilic cytoplasm (Figure 4). In the extracellular space there were irregular arranged collagen fibres intermixed with a few lymphocytes (Figure 5). Other areas showed mature collagen (scar tissue) with prominent vessels, blood resorption and hemosiderosis. Immunohistochemically the neoplastic cells were faintly positive for vimentin (Figure 6). They were negative for desmin and v. Willebrand-factor.

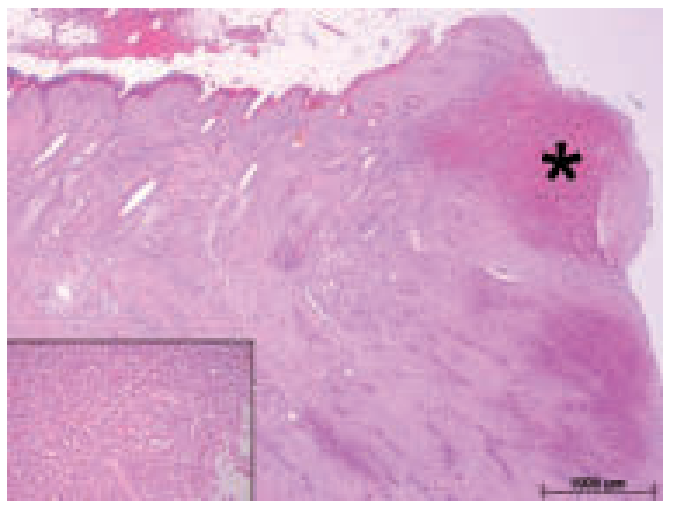

Fig. 3 Histological picture of the margin of the ulcerated skin. There are acute hemorrhages (asterisk) and in the deeper areas a chronic suppurative inflammation and formation of a juvenile granulation tissue (inset) was observed. Haematoxylin \& Eosin stain.

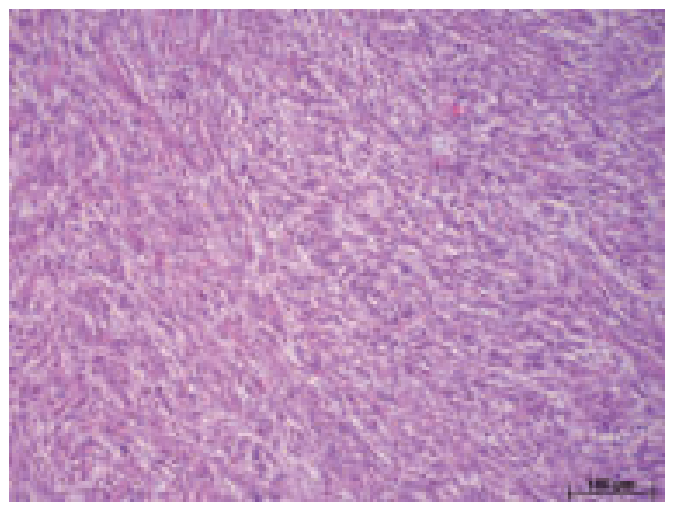

Fig. 4 Histological picture of the fibrosarcoma, note the monomorphous population of spindle cells, arranged in bundles, admixed with a few lymphocytes. Haematoxylin \& Eosin stain.

\section{Discussion}

Pathologic changes in the saddle region, such as hyper- or hyposensitivity, swelling or sores, are not uncommon in horses used for riding purpose. These changes often cause, as presented in this case report, resistance to work, intermittent lameness, stumbling, falling or hypersensitivity to being saddled or even brushed (Harman 1999). Repetitive traumatisms, 
such as an ill-fitting saddle, or a unique traumatism, such as a kick or bite, might cause a pathological swelling in the saddle region (Harman 1999, Von Peinen et al. 2010). Other causes might be foreign bodies, such as wood or metals, e.g. broken needles; injections in the saddle and back region, frequently performed for diagnostic respectively therapeutic purpose (Holm et al. 2006, Allen et al. 2010) or the local application of different substances. Epidermal (infundibular) and dermoid cysts (Hillyer et al. 2003) are often situated in the saddle region and might increase in size, when inflamed or infected and might be calcified. Habronemiasis might also

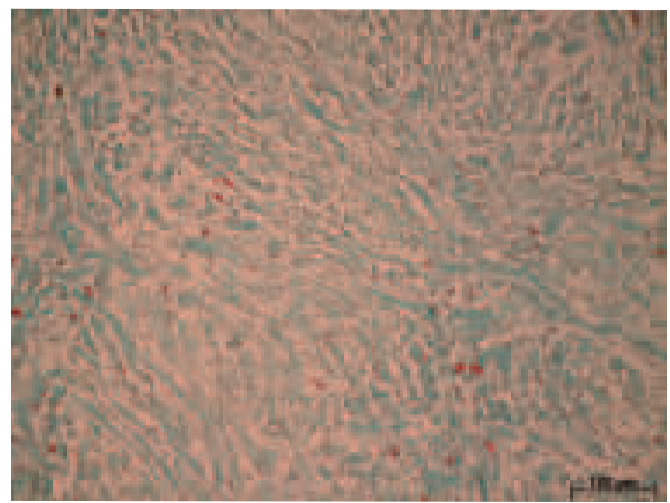

Fig. 5 Demonstration of intensely green stained collagen fibres between neoplastic cells. Goldner stain.

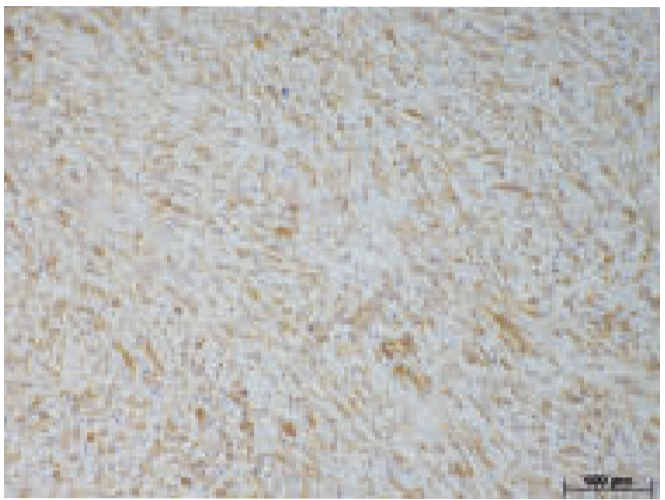

Fig. 6 Neoplastic cells are faintly positive for vimentin. ABC method.

cause a firm swelling of variable diameter and might not present any cutaneous lesion (Mohamed et al. 1990). Cutaneous and fibroblastic neoplasias, such as fibroma, sarcoma, and leiomyoma occur in horses (Cotchin 1977). The equine sarcoid might furthermore cause a firm soft tissue swelling. In the case described different causes were excluded by clinical examination and diagnostic imaging techniques. There was no suspicion of a neoplastic tissue and according to an earlier case a successful surgery of a simple calcinosis circumscripta was expected. Even intra operationem there was no sign of a neoplastic tissue. Besides the calcified plate and the coagulated blood there was no abnormal mass to feel in the soft tissue surrounding the swelling, which had to be taken out of the surgery wound. The indication for a histologic examination of tissue out of the surgery wound were the long term not healing of the wound combined with an intermittend profus bleeding. A fibrosarcoma was only diagnosed by histopathology and immunohistochemistry after the horse was euthanized. Examination of tissue taken out deep of the musculous tissue of the wound earlier revealed no significant results to confirm a neoplasia.

Fibrosarcoma is a malignant tumor of fibroblasts with variable amounts of collagen (Hendrick et al. 1998). This neoplasia appears, corresponding to the described case, solitary to multi-nodular, grey whitish and poorly demarqued with tendency to infiltrate deep structures, e.g. muscles, tendons, and tendency to ulcerate the overlying epidermis (MacEwen und Withrow 1996, Story et al. 2005). This malignant tumor is uncommon in horses and comprises about $2 \%$ of musculocutaneous and cutaneous neoplasias in this species (Story et al. 2005, Valentine 2006). The incidence of fibrosarcomas reported in the literature range between $0.4 \%$ and 46.4\% (Miller und Campbell 1982, Bastinello 1993). The broad inconsistency in these data might be based on the classification of fibrosarcoma and equine fibroblastic sarcoids (Story et al. 2005), whereas equine fibrosarcomas are locally invasive (in the deeper structures) with rare reports of metastases (Jorgensen et al. 1997). In case of metastasis the lung and liver are described to be predisposed sites in horses (Jorgensen et al. 1997, Reinertson 1974). In horses, the occurrence of fibrosarcoma is described to be associated with a vaccine-injection (Kannegieter et al. 2010) and burning injuries (Schumacher et al. 1987). This malignant tumour is described to occur in all age-groups from foal (Schmotzer et al. 1987) to adult horses (Barber et al. 1983, Fulton und Stickle 1989, Jorgensen et al. 1997). Cytology is of limited value for diagnosis, because of the similar cytological appearance of reactive tissue and benign neoplasm (MacEwen und Withrow 1996). Diagnostic imaging techniques might also be valuable for diagnostic purpose. In the case described, an osseous structure was diagnosed in the soft tissue by using radiology and ultrasonography. Fibrosarcoma associated with osseous metaplasia has already been reported previously (Kannegieter et al. 2010). The final tumor diagnosis is based on the histo-pathologic appearance (Ramaekers et al. 1988) and on the morphologic aspect of the tissues and cells (Story et al. 2005). Complementary techniques give additional information relevant to tissue type and cells (Ramaekers et al. 1988). Immunohistochemistry shows, as in the case described, a positive staining of vimentin, and a negative for factor VIII, S100 protein, desmin and actin (Ramaekers et al. 1988).

The therapy of fibrosarcoma consists in a wide surgical excision of the mass, i.e. the margin of about $3 \mathrm{~cm}$ in the normal tissue (MacEwen und Withrow 1996), as described. Primary wound healing was initially intended because of the surgical site, the risk of dehiscence / tension and the risk of contamination. Adjunct therapies can be added to surgical excision, e.g. radiation therapy, chemotherapy or immunotherapy. In equine tumour therapy brachytherapy (Théon und Pascoe 1995), teletherapy (Riggott und Quarmby 1980, Théon 1998), and mainly local chemotherapy (Théon et al. 2007) are described. In the case described, radiation therapy or systemic chemotherapy was not an option. The recurrencerate for fibrosarcoma is high after surgical excision and larger fibrosarcomas respond poorly to radiation therapy or chemotherapy (MacEwen und Withrow 1996). These neoplasias might re-occur even years after therapy. In this case report the horse was euthanized because of the non-healing wound and the grave prognosis. 
In conclusion, fibrosarcoma is a rarely occurring neoplasia in horses. This malignant tumor should be taken into consideration in case of wound-healing disorders associated with intermittently profusely bleeding tissue.

\section{References}

Allen A. K., Johns S., Hyman S. S., Sislak M. D., Davis S. and Amory J. (2010) How to diagnose and treat back pain in the horse. Proc. Annu. Meet. Am. Assoc. Equine Pract. 384-388

Barber S. M., Clark E. G. and Fretz P. B. (1983) Fibroblastic tumor of the premaxilla in two horses. J. Med. Vet. Assoc. 182, 700-702

Bastinello S. S. A. (1983) Survey on neoplasia in domestic species over a 40-year period from 1935 to 1974 in the republic of South Africa IV. Tumors occurring in Equidae Onderstepoort J. Vet. Res. $50,91-96$

Cotchin E. (1977) A general survey of tumours in the horse. Equine Vet. J. 9, 16-21

Fulton I. C. and Stickle R. (1989) What is your diagnosis? Probable neoplasm of the rostral portion of the mandible. J. Am. Vet. Med. Assoc. 195, 1772-1773

Harman J. (1999) Tack and saddle fit. Vet. Clin. North Am. Equine Pract. 15, 247-261

Hendrick M. J., Mahaffey E. A., Moore F. M., Vos J. H. and Walder E. J. (1998) Histological classification of mesenchymal tumors of skin and soft tissues of domestic animals. In: World Health Organization International Histological Classification of Tumors of Domestic Animals, 2nd ed, Armed Forces Institute of Pathology, American Registry of Pathology, Washington DC 2, 1-64

Hillyer L. L., Jackson A. P., Quinn G. C. and Day M. J. (2003) Epidermal (infundibular) and dermoid cysts in the dorsal midline of a three-year-old thoroughbred-cross gelding. Vet. Dermatol. 14, 205-209

Holm K. R., Wennerstrand J., Lagerquist U., Eksell R. and Johnston C. (2006) Effect of local analgesia on movement of the equine back. Equine Vet. J. 38, 65-69

Jorgensen J. S., Geoly F. J., Berry C. R. and Breuhaus B. A. (1997) Lameness and pleural effusion associated with an aggressive fibrosarcoma in a horse. J. Am. Vet. Med. Assoc. 210, 1328-1331

Kannegieter N. J., Schaaf K. L., Lovell D. K., Simon C. D. and Stone B. M. (2010) Myofibroblastic fibrosarcoma with multifocal osseous metaplasia at the site of equine influenza vaccination. Aust. Vet. J. 88, 132-136

MacEwen E. G. and Withrow S. J. (1996) Soft tissue sarcomas. In: Withrow S.J., MacEwen E.G. eds. Small animal clinical oncology. 2nd ed. Philadelphia: Saunders, 211-220.
Miller R. J. and Campbell R. S. (1982) A survey of granulomatous and neoplastic diseases $f$ equine skin in North Queensland. Aust. Vet. J. 59, 33-37

Mohamed F. H., Abu Samra M. T., Ibrahim K. E. and Idris S. O. (1990) Cutaneous habronemiasis in horses and domestic donkeys (Equus asinus asinus). Rev. Elev. Med. Vet. Pays Trop. 42, 535-540

Ramaekers F. C. S., Vooijs G. P., Huijsmans A. C. L. M. and Salet-Van den Pol M. R. J. (1988) Immunohistochemistry as an aid in diagnostic cytopathology. In: DeLellis RA. ed Advances in Immunohistochemistry. 3rd ed, New York: Raven Press, 133-163

Reinertson E. L. (1974) Fibrosarcoma in a horse. Cornell Vet. 64, 617-621

Riggott J. M. and Quarmby W. B. (1980) Treatment of fibrosarcoma in a horse. Equine Vet. J. 12, 193-196

Schmotzer W. B., Hultgren B. D., Watrous B. J., Wagner P. C. and Kaneps A. J. (1987) Nasomaxillary fibrosarcomas in three young horses. J. Am. Vet. Med. Assoc. 191, 437-439

Schumacher J., Watkins J. P., Wilson S. R. and Foreman M. E. (1986) Burn-induced neoplasia in two horses. Equine Vet. J. 18, 410-412

Story M. R., Gaughan E. M., Andrews G. A. and Balch S. (2005) Fibrosarcoma over the tarsal groove of a 14-month-old Quarter horse. Vet. Comp. Orthop. Traumatol. 18, 115-118

Théon A. P. and Pascoe J. R. (1995) Iridium-192 interstitial brachytherapy for equine periocular tumours: treatment results and prognostic factors in 115 horses. Equine Vet. J. 27, 117-121

Théon A. P. (1998) Radiation therapy in the horse. Vet. Clin. North Am. Equine Pract. 14, 673-688

Théon A. P., Wilson W. D., Magdesian K. G., Pusterla N., Snyder J. R. and Galuppo L. D. (2007) Long-term outcome associated with intratumoral chemotherapy with cisplatin for cutaneous tumors in equidae: 573 cases (1995-2004). J. Am. Vet. Med. Assoc. 230, 1506-1513

Valentine B. A. (2006) Survey of equine cutaneous neoplasia in the Pacific Northwest. J. Vet. Diagn. Invest. 18, 123-126

Von Peinen K., Wiestner T., von Rechenberg B. and Weishaupt M. A. (2010) Relationship between saddle pressure measurements and clinical signs of saddle soreness at the withers. Equine Vet. J. 42, 650-653

Anke Köster

Holperdorperstr 44

49170 Hagen a.T.W.

anke.koester@web.de 